\title{
Initial growth, production in consecutive years and biochemical changes on tomato cultivars in organic system with application of Bacillus subtilis
}

\author{
Crecimiento inicial, producción en años sucesivos y alteraciones bioquímicas en \\ cultivares de tomate en sistema orgánico con aplicaciones de Bacillus subtilis
}

Vanessa Vani Obrzut ${ }^{1}$, Átila Francisco Mógor ${ }^{1 *}$, Sérgio Miguel Mazaro², Gilda Mógor ${ }^{1}$

\begin{abstract}
In this study, Bacillus subtilis were applied on seeds, seedlings, and tomato crops for two years in an organic system. The product Serenade ${ }^{\circledR}$ was used on 'Cardyna' and 'Trinidade' cultivars with the objective of determining the effect of the bacteria on initial plant growth when applied to seeds $\left(50 \mu \mathrm{L}\right.$ per seed) or the seedlings watered with $100 \mathrm{~mL}$ solution at $8 \mathrm{~mL} \mathrm{~L}^{-1}$ concentration, and tomato yield when applied at the concentration of $4 \mathrm{~mL} \mathrm{~L}^{-1}$ in the form of a soil drench, foliar sprays and their combination, considering their action in the promotion of growth and also in the induction of resistance allied to possible metabolic deviations. Seed application reduced initial plant growth, while seedling watering at transplanting promoted growth. Chlorophylls $a, b$ and total chlorophyll, carotenoids, and the enzymes phenylalanine ammonia lyase, chitinase, and $\beta 1,3$ glucanases were stimulated in a variable way among cultivars and applications, indicating the activation of plant defenses. Phenolic compounds, flavonoids, and total sugars were not altered, while the concentrations of reducing sugars were higher due to applications than those of nonreducing sugars. The metabolic changes did not influence the tomato yield.
\end{abstract}

Keywords: enzymes, Plant-growth promoting bacteria, resistance induction, Solanum lycopersicum L., yield.

\section{RESUMEN}

En este estudio se realizaron aplicaciones de Bacillus subtilis en semillas, mudas y en el cultivo del tomate durante dos ciclos en sistema orgánico. Se utilizó el producto Serenade® en los cultivares Cardyna y Trinidad. El objetivo fue determinar el efecto de la bacteria en el crecimiento inicial de las plantas cuando se aplica a las semillas (50 $\mu$ l por semilla) o a las mudas (100 $\mathrm{mL}$ de

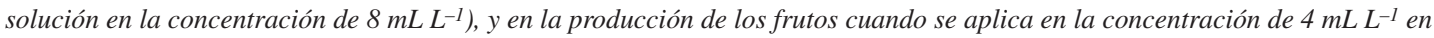
forma de riego, pulverizaciones foliares y su combinación, teniendo en cuenta su acción en la promoción del crecimiento y también en la inducción de resistencia aliada a posibles desvíos metabólicos. La aplicación en las semillas redujo el crecimiento inicial de las plantas, mientras que el riego de las mudas en el momento del trasplante estimuló el crecimiento. Las clorofilas a, b y totales, los carotenoides y las enzimas fenilalanina amonio-liase, quitinasa y $\beta 1,3$ glucanasas fueron estimuladas de forma variable entre cultivares y aplicaciones, indicando la activación de las defensas de las plantas. Los compuestos fenólicos, flavonoides y azúcares totales no se alteraron, mientras que las concentraciones de azúcares reductores fueron mayores debido a las aplicaciones que las de no reductores. Las alteraciones metabólicas no influyeron en la producción de los tomates.

Palabras clave: bacterias promotoras del crecimiento de las plantas, rendimiento, inducción de resistencia, enzimas, Solanum lycopersicum $L$.

\section{Introduction}

The application of alternative techniques such as the use of beneficial microorganisms in farming becomes relevant for food production. Regarding microorganisms, the use of growth-promoting bacteria and pant-resistance inducers is an option that is compatible with the criteria of sustainability, becoming an alternative for reducing the use of synthetic products (Shaharoona et al., 2008).

\footnotetext{
1 Universidade Federal do Paraná (UFPR), Departamento de Fitotecnia e Fitossanitarismo, Curitiba, PR, Brasil.

2 Universidade Tecnológica Federal do Paraná (UTFPR), Unidade Sudoeste do Paraná, Dois Vizinhos, PR, Brasil.

* Corresponding author: atila.mogor@ufpr.br
}

Fecha de Recepción: 22 de Octubre, 2017.

Fecha de Aceptación: 15 de Septiembre, 2020. 
Hence, bacteria of the genus Bacillus are known to promote plant growth, as the effect reported by Harthmann et al. (2010) when identifying the action of $B$. megaterium on the growth and yield improvement in onions. Besides, B. subtilis-based products are used for the biological control of plant diseases (Halfeld-Vieira et al., 2016).

As a result, the activation of plant defenses through the synthesis of proteins such as chitinases and $\beta 1,3$ glucanases in tomato plants was observed using of B. subtilis, indicating that this bacterium induces systemic resistance against certain pathogens (Chowdappa et al., 2013).

Resistance-inducers can be biotic or abiotic products. When applied to plants, they induce defense responses (Durrant and Dong, 2004), resulting in productivity gains as they reduce pathogen severity. However, the physiological cost of inducing resistance may result in changes in the growth and development of the plant, as reported by Karasov et al. (2017), due to the deviation of photoassimilates from the primary to the secondary metabolism of plants, which is related to the synthesis of the defense compounds.

Therefore, the objective of this study was to evaluate different ways of applying the commercial product Serenade ${ }^{\circledR}$ containing $B$. subtilis in two cultivars of tomato plants through the validation of its effects on the initial growth of the plants with application in seeds and seedlings. Its use was also assessed in the cultivation in an organic system in a protected environment for two cycles, pursuing the identification of possible effects of the induction of resistance on the yield and biochemical changes in tomato plants.

\section{Material and methods}

\section{Experiment installation}

Two experiments were carried out using Serenade ${ }^{\circledR}$ product (Bayer S.A. ${ }^{\circledR}$ ), a concentrated aqueous suspension of the bacterium Bacillus subtilis (BS) line QST 713 at the maximum concentration of $13.68 \mathrm{~g} / \mathrm{L}$ of endospores of the formulated product $(1.34 \% \mathrm{p} / \mathrm{v})$ with a maximum of $1.76 \times 10^{10}$ viable $\mathrm{CFU} / \mathrm{g}$. The experiments were conducted at the organic vegetable production research area, where an organic system was implemented 10 years ago, at the Federal University of Paraná, under the geographical coordinates $25^{\circ} 25 \mathrm{~S}$ and $49^{\circ} 0^{\prime} \mathrm{W}$ at an altitude of
$920 \mathrm{~m}$. The climate in the region is temperate type $\mathrm{Cfb}$, according to the Köppen classification.

The objective of the first experiment was to evaluate the effect of $B S$ applied to seeds and seedlings on the initial growth of two tomato cultivars, and the objective of the second one was to determine the effect of $B S$ on the production and biochemical variables of the cultivars, conducted in the same area in successive years, in a protected environment in a high tunnel-type greenhouse. For both experiments, it was used seeds of 'Cardyna' and 'Trinidade' (HM. Clause ${ }^{\circledR}$ ) tomato cultivars with an indeterminate habit, oblong fruits (Italian type) with an average weight of 160 grams, both with multiple tolerances (HM. Clause ${ }^{\circledR}$ ), suitable for organic production.

\section{Experiment with applications in seeds and seedlings}

Sowing was carried out in expanded 200-cell polystyrene trays with unit cell volume corresponding to $18 \mathrm{~cm}^{3}$, filled with a substrate composed of composted poultry litter (Provaso ${ }^{\circledR}$ ) combined with composted pine bark in an 1:2 ratio. One seed per cell was distributed at a depth of $1 \mathrm{~cm}$. The seedlings were kept in a nursery with micro-spray timed irrigation until 30 days after sowing (DAS) when they were transplanted to 3.6-L pots filled with the same compounds and proportions.

The treatments consisted of two $B S$ application methods: (i) inoculation of the seeds in $50 \mu \mathrm{L}$ of $B S$ for each seed, which were left to dry in the shade on paper towels and then were soon seeded, and at 30 DAS were transplanted to the pots; (ii) use of seedlings from non-inoculated seeds, watered with $100 \mathrm{~mL}$ of a solution containing $8 \mathrm{~mL} \mathrm{~L}^{-1}$ of $B S$, applied to the pots at transplanting; (iii) seedlings from non-inoculated seeds and no application of a solution to the pots as a control. The experimental design was completely randomized, in a $3 \times 2$ factorial scheme, with one control and two forms of application of $B S$ in two cultivars of tomato plants, with five replicates composed of two pots with one plant each, totaling ten pots per treatment.

The plants were collected 30 days after transplanting (DAT) when the first inflorescences appeared. The aerial part area was determined using WinRhizo ${ }^{\circledR}$ software coupled to a LA1600 Scanner (Regent Systems, Quebec, Canada), and fresh and dry mass of the leaves, stem, and root were determined 
(Shimadzu AUY 220 analytical balance). The dried masses were obtained in a forced air circulation oven at $65^{\circ} \mathrm{C}$ until reaching a constant weight.

\section{Experiments with application in consecutive crops in organic system}

The experiment was conducted in consecutive years, totaling two cycles of cultivation in the same area. The first cultivation had its sowing in September and transplanting of seedlings with no treatment in October 2013, and harvested until March 2014. The second cycle, with sowing in September and transplanting of the seedlings in October 2014 and harvest until March 2015, both with 200 plants arranged in the spacing of $0.65 \mathrm{~m}$ between plants and $1.20 \mathrm{~m}$ between rows, resulting in a population equivalent to 12,820 plants per hectare.

Soil chemical analysis in the experimental area $(0-20 \mathrm{~cm})$ showed the following values: $\mathrm{pH}\left(\mathrm{CaCl}_{2}\right)$ = 5.5; $\mathrm{pHSMP}=6.6 ; \mathrm{Al}^{+3}=0 ; \mathrm{H}+\mathrm{Al}=2.2 \mathrm{cmol}_{\mathrm{c}}$ $\mathrm{dm}^{-3} \mathrm{Ca}^{+2}=8.0 \mathrm{cmol}_{c} \mathrm{dm}^{-3} ; \mathrm{Mg}^{+2}=4.1 \mathrm{cmol}_{\mathrm{C}} \mathrm{dm}^{-3}$; $K^{+2}=1.45 \mathrm{cmol}_{c} \mathrm{dm}^{-3 ;} \mathrm{P}=38.3 \mathrm{cmol}_{c} \mathrm{dm}^{-3} ; \mathrm{C}=38 \mathrm{~g}$ $\mathrm{dm}^{-3} ; \mathrm{V} \%=86 ; C E C=15.75 \mathrm{cmol}_{c} \mathrm{dm}^{-3}$ (Unithal Tecnologia e Comércio de Produtos Agropecuários Ltda). For maintenance of the high fertility identified in the chemical analysis, it was applied the amount of $5 \mathrm{tha}^{-1}$ of organic compound presenting the following contents: $\mathrm{pH} 7.1 ; \mathrm{P}=14.00 \mathrm{~g} \mathrm{Kg}^{-1} ; \mathrm{K}=11.3 \mathrm{~g} \mathrm{Kg}^{-1} ; \mathrm{Ca}=$ $31.7 \mathrm{~g} \mathrm{Kg}^{-1} ; \mathrm{Mg}=6.8 \mathrm{~g} \mathrm{Kg}^{-1}$; and $\mathrm{C}: \mathrm{N}$ ratio $=27.6$.

At the tomato crops intervals, black oats (Avena strigosa) were grown as a recommended practice in organic systems (Mógor and Câmara, 2009). In both cycles, the plants were conducted with two stems and grown vertically with ribbons. The determination of growth by removal of the apical meristem occurred after the emission of the tenth rachis.

In each cycle, 32 plots with five plants each were implanted. A plant row was also implanted as a border on each side of the greenhouse. Driptape irrigation followed a variable shift to maintain the field capacity at a minimum of $80 \%$, with the aid of tensiometers. The experimental design was completely randomized with a $4 \times 2$ factorial arrangement (control and three forms of application $\mathrm{x}$ two cultivars) with four replications. The application forms were the following: watering in the lap of the plant (drench), foliar spraying, and association of drench and foliar spraying. The concentration of $4 \mathrm{~mL} \mathrm{~L}^{-1}$ of $B S$ was used for both application forms. The applications of the treatments started at 21 DAT at a weekly frequency, continuing until the end of the crop, totaling 16 applications in the leaves and drench. An Herbicat ${ }^{\circledR}$ spray coupled to a $\mathrm{CO}_{2}$ cylinder pressurizing at $40 \mathrm{psi} . \mathrm{cm}^{-2}$ was used for spraying, providing uniform spraying coverage and avoiding run-off and drift, with a volume of 750 L.ha ${ }^{-1}$. The drench was performed by distributing $100 \mathrm{~mL}$ of the solution near the lap of the plant.

Harvesting started at 106 and 109 days after sowing in the first and second cycles, respectively. All 10-raceme fruits were harvested and evaluated. Each fruit was harvested and evaluated when it was $2 / 3$ reddish colored. The equatorial and longitudinal diameter and the fresh mass were determined. The leaves below each raceme were removed after the harvest of all their respective fruits, a practice that combined the rusticity of the cultivars and the protected environment, avoided the proliferation of foliar pathogens. Thus, no evaluation of incidence and severity was performed.

\section{Biochemical determination}

The biochemical analyses were carried out at the Biofertilizer Laboratory in the Crop Science Department at Federal University of Paraná (UFPR) in Curitiba, Brazil, and at the Technological Federal University of Paraná (UTFPR) in Dois Vizinhos, State of Paraná, Brazil. The samplings were carried out at the second tomato growth cycle when the leaves were removed at the early hours in the morning, between 7 and 8 hours, at 116 days after sowing, immediately above the $7^{\text {th }}$ raceme, the middle third of the plant. The leaves were fully expanded with no symptoms of pathogen or pest attack or nutritional deficiencies. The leaflets were removed from the extremities, and the medium leaflets were trimmed, frozen, and macerated with liquid nitrogen. Triplicates were used to obtain the means.

At the UFPR, for the extraction of chlorophyll $a(663 \mathrm{~nm})$, chlorophyll $b(647 \mathrm{~nm})$, and carotenoids $(470 \mathrm{~nm})$, the methodology described by Pompelli et al. (2013) was followed using acetone and calcium carbonate and spectrophotometer reading (BEL 2000 UV/VIS). Reducing and non-reducing sugars were determined using the DNS method. The phenolic compounds were determined by the adaptation of the Prussian Blue method. The flavonoids contents were determined using the adapted method of Eghdami and Sadeghi (2010), which is based on the formation of complexes that react with aluminum. 
At the UTFPR, protein determination and phenylalanine ammonia-lyase activity (PAL), chitinase, and $\beta 1,3$ glucanase enzymes were performed. The adaptation of the method described by Bradford (1976) in which the complete protein reading was performed in a 590-nm spectrophotometer using bovine serum albumin as standard to determine the total protein concentration. The determination of phenylalanine ammonia-lyase activity (PAL) was performed based on the difference in absorbance resulting from the conversion of phenylalanine to trans-cinnamic acid. For the determination of chitinase and B-1,3-glucanase activities, the enzymatic activity of chitinase was assessed by the Busso and Mazaro (2015) method. For the spectrophotometric determination of $\beta-1,3-$ glucanase activities in the extracts, bright blue curdlan-remazol (Sigma Aldrich ${ }^{\circledR}$ - $4 \mathrm{mg} \mathrm{mL}^{-1}$ ) was used as the substrate.

\section{Statistical analyses}

Data were tested for homogeneity of the variances using the test of Bartlett and submitted to ANOVA. When significant, means were compared by the test of Tukey $(p<0.05 \% ; p<0.01 \%)$, using Assistat $^{\circledR} 7.7$ Beta software.
Table 1. Mean values of the aerial part area $\left(\mathrm{cm}^{2}\right)$ of 'Cardyna' and 'Trinidade' tomato cultivars at 60 days after sowing, submitted to Bacillus subtilis (Serenade ${ }^{\circledR}$ ) application in the form of seeds inoculation, seedling watering, and control without application.

\begin{tabular}{lccc}
\hline & \multicolumn{3}{c}{ Aerial part area $\left(\mathrm{cm}^{2}\right)$} \\
\cline { 2 - 4 } & $\begin{array}{c}\text { Seeds } \\
\text { inoculation }\end{array}$ & $\begin{array}{c}\text { Seedling } \\
\text { watering }\end{array}$ & Control \\
\hline Cardyna & $2.314 \mathrm{Bb}$ & $3.279 \mathrm{Ab}$ & $2.428 \mathrm{Ba}$ \\
Trinidade & $3.568 \mathrm{Ba}$ & $4.247 \mathrm{Aa}$ & $2.034 \mathrm{Ca}$ \\
C.V $(\%)$ & 12.51 & & \\
\hline
\end{tabular}

Means followed by the same lower-case letter in the columns and upper-case letter in the rows are not different from each other by the test of Tukey $(p<0.05)$.

\section{Results and discussion}

\section{Experiment with application in seeds and seedlings}

The results showed that $B S$ watering at seedling transplant stimulated plant growth in both cultivars (Table 1), and consequently, the accumulation of fresh (Table 2) and dry (Table 3) mass in a variable manner between the cultivars over the initial growth.

Table 2. Fresh mass of leaves, stems, and roots of tomato cultivars 'Cardyna' and 'Trinidade' at 60 days after sowing, submitted to Bacillus subtilis (Serenade ${ }^{\circledR}$ ) application in the form of seed inoculation, seedling watering, and control without application.

\begin{tabular}{lllll}
\hline & Seeds inoculation & Seedling watering & Control & Cultivars \\
\hline Leaf fresh mass (g) & & & & \\
\hline Cardyna & 49.82 & 62.67 & 45.22 & $52.57 \mathrm{~b}$ \\
Trinidade & 59.55 & 74.20 & 66.95 & $66.90 \mathrm{a}$ \\
Mean (T) & $54.68 \mathrm{~B}$ & $68.43 \mathrm{~A}$ & $56.08 \mathrm{~B}$ & \\
\hline C.V. (\%) & 14.10 & & & \\
\hline Stem fresh mass (g) & & & & \\
\hline Cardyna & 41.45 & 56.87 & 37.85 & $45.39 \mathrm{~b}$ \\
Trinidade & 53.80 & 75.00 & 58.40 & $62.40 \mathrm{a}$ \\
Mean (T) & $47.62 \mathrm{~B}$ & $65.93 \mathrm{~A}$ & $48.12 \mathrm{~B}$ & \\
\hline C.V. (\%) & 16.44 & & & \\
\hline Root fresh mass (g) & & & & \\
\hline Cardyna & 13.40 & 11.99 & $13.65 \mathrm{~b}$ \\
Trinidade & 16.14 & & & \\
Mean (T) & $14.77 \mathrm{~B}$ & $18.47 \mathrm{~A}$ & $14.33 \mathrm{~B}$ & \\
\hline C.V (\%) & 17.69 & & & \\
\hline
\end{tabular}

Means followed by the same lower-case letter in the columns and upper-case letter in the rows are not different from each other by the test of Tukey $(p<0.05)$. 
Table 3. Dry mass of leaves stems, and roots of tomatoes of 'Cardyna' and 'Trinidade' cultivars submitted to the Bacillus subtilis (Serenade ${ }^{\circledR}$ ) application methods in the form of seed inoculation, seedling watering, and control with no application at 60 DAS.

\begin{tabular}{lllll}
\hline & Seeds inoculation & Seedling watering & Control & Cultivars \\
\hline Leaf dry matter $(\mathrm{g})$ & & & & \\
\hline Cardyna & 4.80 & 5.43 & 5.45 & $5.23 \mathrm{~b}$ \\
Trinidade & 5.92 & 6.84 & 6.59 & $6.45 \mathrm{a}$ \\
Mean $(\mathrm{T})$ & $5.36 \mathrm{~B}$ & $6.13 \mathrm{~A}$ & $6.02 \mathrm{~A}$ & \\
\hline C.V (\%) & 2.71 & & \\
\hline Stem dry matter $(\mathrm{g})$ & & & \\
\hline Cardyna & $2.99 \mathrm{Cb}$ & $5.10 \mathrm{Ab}$ & $4.18 \mathrm{Bb}$ & \\
Trinidade & $4.48 \mathrm{Ba}$ & $5.89 \mathrm{Aa}$ & $4.63 \mathrm{Ba}$ & \\
Mean (T) & & & \\
\hline C.V (\%) & 2.73 & & \\
\hline Root dry matter $(\mathrm{g})$ & & & \\
\hline Cardyna & & & \\
Trinidade & $0.88 \mathrm{Bb}$ & & \\
Mean (T) & $1.01 \mathrm{Ba}$ & & \\
\hline C.V (\%) & & & \\
\hline
\end{tabular}

Means followed by the same lower-case letter in the columns and upper-case letter in the rows are not different from each other by the test of Tukey $(p<0.05)$.

The increase in the vegetative development of PGPB-treated plants, as observed in the $B S$ watering treatment, identified by the increase in the aerial part area, particularly at the 'Trinidade' cultivar (Table 1), may be related to the cellular elongation promoted by the auxines, considering that Bacillus may be the producers of this hormone (SzilagyiZecchin et al., 2015).

According to Walia et al. (2014), auxin is quantitatively the most abundant hormone secreted by PGPB besides being the main factor responsible for the higher growth of plants submitted to treatments with these microorganisms, both roots and aerial part, as shown in Table 2. Moreover, the mean values of the fresh mass of leaves, stems, and roots increased through watering with $B S$. Among cultivars, 'Trinidade' presented the most significant values of the fresh mass of leaves, stems, and roots.

Adesemoye et al. (2008) report that after 60 DAS, a period equivalent to that in this study, the dry mass of tomato plants treated with B. subtilis increased significantly, corroborating what was observed in the present study with 'Trinidade,' which showed an increase in the dry mass of the stems in $B S$ watering treatment (Table 3).
However, application to the seeds at sowing did not alter the fresh mass of the plants compared to the control (Table 2). Nevertheless, it reduced growth, especially in the 'Cardyna' (Table 1) cultivar. It also reduced leaf dry mass accumulation in both cultivars, the dry mass of the stem in 'Cardyna' and the root in 'Trinidade' at values lower than those observed in control (Table 3). Szilagyi-Zecchin et al. (2015) reported that application of Bacillus amiloliquefasciens on seeds promoted positive effects but stressed that excessive concentration of the bacterium might reduce plant growth. So, it is likely that the use of $50 \mu \mathrm{L}$ of the Serenade ${ }^{\circledR}$ commercial product for each seed with no dilution was excessive, and its dilutions should be tested in further studies.

\section{Applications in consecutive years in organic system}

Data analysis did not identify interactions between cultivars and forms of $B S$ application and changes in mass, number, and yield of fruits of the cultivars in the two cycles, either.

The average fruit mass of both cultivars ranged from 107.52 to $115.61 \mathrm{~g}$ in their first cycle, and 
from 98.32 to $113.06 \mathrm{~g}$ in their second cycle, with an average number of fruits per plant ranging from 48.02 to 52,22 between cycles and cultivars. The average fruit yield in this study varied from 4.8 to $5.4 \mathrm{~kg}$ per plant, which is equivalent to the production obtained by Luz et al. (2007) in the conventional system, from 3.0 to $5.0 \mathrm{~kg}$ per plant, and $4.0 \mathrm{~kg}$ in the organic system.

\section{Biochemical changes}

Babu et al. (2015) reported that PGPB might promote increases in plant chlorophyll content, as observed in leaf applications of $B S$, stimulating the synthesis of chlorophylls and also of carotenoids. However, the drench and its spraying combination did not alter the pigment contents, nor was there any interaction between forms of $B S$ application and cultivars. By comparing the cultivars, 'Cardyna' presented higher levels of chlorophylls and carotenoids (Table 4), indicating a characteristic of the genotype as no interaction with the forms of $B S$ application was found.

Alteration in the pigments promoted by $B S$ in 'Cardyna' were not sufficient to promote the increase in the sugar content in the leaves. On the contrary, the foliar spraying diminished the contents of reducing sugar on cultivars, while drench and the combination of the applications decreased the content of non-reducing sugars (Table 5). The content of total sugars was not influenced by the manners in which $B S$ was applied, nor did it vary significantly among cultivars, with mean values of $7352 \mu \mathrm{g}$ in 'Cardyna' and $6961 \mu \mathrm{g}$ g in 'Trinidade.'

The plant-bacteria association may provide the activation of several metabolic pathways of sucrose, which is the primary non-reducing sugar, combined with glucose and fructose, which is one of the reasons for stimulating the growth of plants, according to Kang et al. (2014). The authors reported that plants treated with bacteria from the PGPB group obtained an increase in the contents of chlorophyll, total sugars, and reducing sugars. However, in the present study, the chlorophylls' increased contents did not reflect any increase in the sugars.

Drench application stimulated the accumulation of non-reducing sugars in 'Trinidade', while drench + spraying, on the other hand, caused a reduction in the contents. Consequently, of the total amount of the sugars of the plants, the greater fraction was that of reducing sugars.

Mazaro et al. (2009) state that the increase in the reducing sugars may be related to the increase in the metabolic activity through the induction of compound production related to the expression of resistance against diseases. However, this is not characterized in this work as the higher content of reducing sugars also occurred in the control group, possibly relating to the role of the leaf as a source of photoassimilates for nearby fruits.

The induction of defense activates mechanisms that already exist in the plant and may involve the synthesis of $\beta-1,3$-glucanase enzymes, chitinase,

Table 4. Mean values of Chlorophyll a, b, total chlorophyll and carotenoids (mg per gram of plant material) of 'Cardyna' and 'Trinidade' tomato leaves, submitted to Bacillus subtilis

(Serenade ${ }^{\circledR}$ ) applications in the form of drench, foliar spraying, drench combined with sprays and control with no application.

\begin{tabular}{lcccc}
\hline & Chlorophyll a & Chlorophyll b & Total chlorophyll & Carotenoids \\
\hline Application forms & & & & \\
\hline Control & $0.225 \mathrm{~b}$ & & $0.360 \mathrm{~b}$ & $0.140 \mathrm{~b}$ \\
Foliar sprays & $0.274 \mathrm{a}$ & $0.170 \mathrm{a}$ & $0.444 \mathrm{a}$ & $0.183 \mathrm{a}$ \\
Drench+ foliar sprays & $0.207 \mathrm{~b}$ & $0.144 \mathrm{ab}$ & $0.352 \mathrm{~b}$ & $0.140 \mathrm{~b}$ \\
Dernch & $0.218 \mathrm{~b}$ & $0.156 \mathrm{ab}$ & $0.375 \mathrm{~b}$ & $0.149 \mathrm{~b}$ \\
\hline Cultivars & & & \\
\hline Cardyna & $0.250 \mathrm{a}$ & $0.162 \mathrm{a}$ & $0.421 \mathrm{a}$ & $0.164 \mathrm{a}$ \\
Trinidade & $0.212 \mathrm{~b}$ & $0.135 \mathrm{~b}$ & $0.353 \mathrm{~b}$ & $0.141 \mathrm{~b}$ \\
C.V.\% & 7.82 & 11.03 & 8.78 & 6.57 \\
\hline
\end{tabular}

Means followed by the same lower-case letter in the columns are not different from each other by the test of Tukey $(p<0.05)$. 
Table 5. Mean values of reducing and non-reducing sugars expressed in $\mu \mathrm{g}$ per gram of plant material of 'Cardyna' and 'Trinidade' tomato leaves, submitted to Bacillus subtilis (Serenade ${ }^{\circledR}$ ) application in the form of drench, foliar spraying, drench combined with sprays and control with no application.

\begin{tabular}{lcccr}
\hline & Drench & Foliar spray & Drench + spray & Control \\
\hline Reducing sugars $(\mu \mathrm{g} / \mathrm{g})$ & & & & \\
\hline Cardyna & $5803 \mathrm{Aa}$ & $4420 \mathrm{Ba}$ & $\begin{array}{l}5341 \mathrm{ABb} \\
6810 \mathrm{Aa}\end{array}$ & $\begin{array}{l}5930 \mathrm{Aa} \\
5223 \mathrm{Ba}\end{array}$ \\
$\begin{array}{lccc}\text { Trinidade } \\
\text { C.V.\% }\end{array}$ & $9,03 \mathrm{Bb}$ & $5083 \mathrm{Ba}$ & & \\
\hline Non-reducing sugars $(\mu \mathrm{g} / \mathrm{g})$ & & & & \\
\hline Cardyna & $1619 \mathrm{Bb}$ & $2100 \mathrm{ABa}$ & $1666 \mathrm{Ba}$ & $2259 \mathrm{Aa}$ \\
Trinidade & $2483 \mathrm{Aa}$ & $1747 \mathrm{Ba}$ & $896 \mathrm{Cb}$ & $1768 \mathrm{Bb}$ \\
\hline C.V.\% & 12,57 & & & \\
\hline
\end{tabular}

Means followed by the same lower-case letter in the columns and upper-case letter in the rows are not different from each other by the test of Tukey $(p<0.05)$.

phenylalanine ammonia-lyase, polyphenoloxidase, and the rise in the concentration of phenolic compounds and flavonoids in plants (Cavalcanti et al., 2006).

The BS treatments did not influence the accumulation of phenolic compounds in tomato plants. Also, the difference between cultivars was not significant (Table 6), despite the greater accumulation reported by Ownley and Windham (2010) as frequently related to resistance induction processes. The phenolic compound values ranged

Table 6. Mean values of total free proteins $\left(\mathrm{mg} \mathrm{g}^{-1}\right)$, phenylalanine ammonia-lyase (PAL) expressed as UAbs/min/mg protein, chitinase expressed in U.E.mg.protein, and $\beta 1,3$ glucanases in U.E/mg, in leaves of 'Cardyna' and 'Trinidade' tomatoes, submitted Bacillus subtilis (Serenade ${ }^{\circledR}$ ) application in the form of watering, foliar spraying, watering combined with foliar spraying, and control with no application.

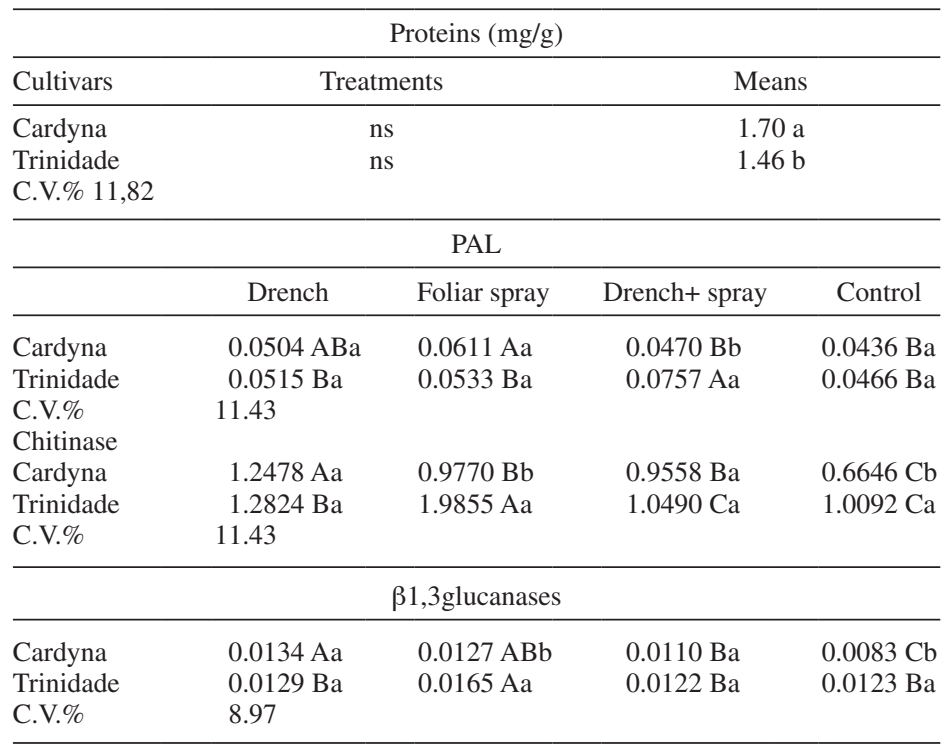

Means followed by the same lower-case letter in the columns and upper-case letter in the rows are not different from each other by the test of Tukey $(p<0.05)$. 
from 3990 mg.g $\mathrm{g}^{-1}$ in 'Cardyna' to $4127 \mathrm{mg} . \mathrm{g}^{-1}$ in 'Trinidade.' Likewise, contents of flavonoid did not express differences between the application forms or cultivars, with 'Cardyna' presenting $1875 \mathrm{mg}$ and 'Trinidade' with 1873 mg.g ${ }^{-1}$. Therefore, it can be inferred from the results obtained in this study that the tomato plants did not receive any stimuli for the increase in the phenolic compounds with the $B S$ applications.

In general, increases in total free proteins may be associated with resistance induction processes related to increased specific enzymes (Lawrence et al., 2000). However, the content of these proteins in tomato leaves was not influenced by $B S$ applications. By comparing the tomatoes, 'Cardyna' presented a higher value than 'Trinidade,' identifying a characteristic of the cultivar.

As no alteration occurred in the content of free proteins, $B S$ treatments promoted a rise in phenylalanine ammonia-lyase (PAL) (Table 6), an enzyme that affects the synthesis of salicylic acid, phenylpropanols, flavonoids, and phytoalexins (Gerasimova et al., 2005). Despite acting on the metabolic pathway of flavonoid synthesis, the increment in PAL did not reflect any increase in phenolic compounds, as already reported.

According to Olivares et al. (2015), foliar spraying with PGPB may promote an increase in PAL activity. Combined with $B S$ applications, the increments varied according to the manner of application and cultivar, showing some interactions. The highest value was found in 'Cardyna' when submitted to foliar spraying, while in 'Trinidade,' it occurred when drench was combined with spraying (Table 6).

Besides the changes in PAL, the presence of chitinases, enzymes that stimulate the hydrolysis of the $\beta 1,4$ bonds of the $\mathrm{N}$-acetylglicosamines, components of chitin in fungal cell walls, was increased in 'Cardyna' through drench with $B S$, while in 'Trinidade', the chitinase was increased by foliar spraying.

According to Lawrence et al. (2000), there is a synergism between chitinase and $\beta 1,3$ glucanases. Moreover, $B S$ treatments promoted increases in the concentrations of both enzymes in the leaf tissue of tomato plants. The increase in $\beta 1,3$ glucanases occurred variably between treatments and cultivars, where drench promoted the highest value for 'Cardina', and foliar spraying for 'Trinidade,'indicating that $B S$ stimulated the accumulation of the enzyme even in plants that did not show any disease symptoms.

The changes in the activity of PR-proteins such as PAL, $\beta 1,3$ glucanases, and chitinases may allow the monitoring of the resistance status of plants when exposed to pathogens (Choudhary et al., 2007). In this study, the incidence of diseases in plants was not identified because of the growth conditions and cultivars, so the enzymatic changes refer to $B S$ applications.

By considering that the same substrates of the primary metabolism that activate pathways of plant growth and development such as phosphoenolpyruvate in the route of glycolysis or erythrose-4-phosphate of pentoses are also responsible for supplying the secondary metabolism. Such as phenylpropanols whose key enzyme is PAL, Carvalho (2012), stated that plants stimulated to activate defense mechanisms even without the presence of pathogens, may present metabolic costs resulting in the reduction in production.

Nevertheless, although the activation of defense mechanisms related to PR-proteins with variable $B S$ applications between treatments and cultivars, the production and characteristics of 'Cardyna' and 'Trinidade' fruits in two crop cycles were not affected, being equivalent to the genetic potential of the cultivars and the results obtained in other studies.

\section{Conclusions}

The application of Bacillus subtilis in the seeds reduced the initial growth of the plants while, watering of the seedlings at transplanting stimulated it. In the cultivations, variability between cultivars, and application forms, the chlorophylls, a, b and total chlorophylls, the carotenoids, and the enzymes related to the defense of the plants were stimulated. Phenolic compounds, flavonoids, and total sugars were not altered. The concentrations of reducing sugars were higher than those of non-reducing sugars. The metabolic changes did not influence the yield of tomato plants in the organic system. 


\section{Literature cited}

Adesemoye, A.O., Obini, M., Ugoji, E.O.

2008. Comparison of plant growth-promotion with Pseudomonas aeruginosa and Bacillus subtilis in three vegetables. Brazilian Journal of Microbiology, 39: 423-426.

Babu, A.N., Jogaiah, S., Ito, S., Nagaraj, A.K., Tran, L.P.

2015. Improvement of growth, fruit weight and early blight disease protection of tomato plants by rhizosphere bacteria is correlated with their beneficial traits and induced biosynthesis of antioxidant peroxidase and polyphenol oxidase. Plant Science, 231: 62-73.

Bradford, M.M.

1976. A rapid and sensitive method for the quantification of microgram quantities of protein utilizing the principle of protein-dye binding. Analytical Biochemistry, 72: 248-254.

Busso, C., Mazaro, S.M.

2015. Utilization of coloidal chitin stained with remazol brilliant blue RSA a sensitive, rapid and economical alternative to detect chitinase in plants. In: 23rd Congress of the International Union for Biochemistry and Molecular Biology (IUBMB), Foz do Iguaçu. Abstracts Book (1) 239 p.

Carvalho, N.L.

2012. Resistência genética induzida em plantas cultivadas. Revista Eletrônica em Gestão, Educação e Tecnologia Ambiental. 7: 1379-1390.

Cavalcanti, F.R., Resende, M.L.V., Zacaroni, A.B., Ribeiro

Junior, P.M., Costa, J.C.B., Souza, R.M.

2006. Acibenzolar-S-metil e Ecolife ${ }^{\circledR}$ na indução de respostas de defesa do tomateiro contra a mancha bacteriana (Xanthomonas vesicatoria). Fitopatologia Brasileira, 31: 372-380.

Choudhary, D.K., Prakash, A., Johri, B.N. 2007. Induced systemic resistance (ISR) in plants: mechanism of action. Indian Journal of Microbiology, 47: 289-297.

Chowdappa, P., Kumar, M., Lashmi, M.J., Upreti, K.K.

2013. Growth stimulation and induction of systemic resistance in tomato against early and late blight by Bacillus subtilis OTPB1 or Trichoderma harzianum OTPB3. Biological Control, 65: 109-117.

Durrant, W.E, Dong, X.

2004. Systemic acquired resistance. Annual Review of Phytopathology, 42: 185-209.

Eghdami, A., Sadeghi, F.

2010. Determination of total phenolic and flavonoids contents in methanolic and aqueous extract of Achillea millefolium. Organic Chemistry Journal, 2: 81-84.

Gerasimova, N.G., Pridvorov, S.M., Ozeretskovskaya, O.L. 2005. Role of phenylalanine ammonia-lyase in the induced resistance and susceptibility of potato plants. Applied Biochemistry and Microbiology, 4: 103-105.

Halfeld-Vieira, B.A., Marinho-Prado, J.S., Nechet, K.L., Morandi, M.A.B., Bettiol, W.

2016. Defensivos agrícolas naturais. Embrapa, Brasília. $853 \mathrm{p}$.

Harthmann, O.E.L., Mógor, A.F., Wordell Filho, J.A., Luz, W.C. 2010. Rizobactérias no crescimento e na produtividade da cebola. Ciência Rural, 40(2): 462-465.
Kang, S.M., Ramalingam, R., You, Y.H., Joo, G.J., Lee, I.J., Lee, K.E., Kim, J.H.

2014. Phosphate solubilizing Bacillus megaterium mj1212 regulates endogenous plant carbohydrates and amino acids contents to promote mustard. Plant Growth.Indian Journal Microbiology, 54: 427-433.

Karasov, T., Chae, E., Herman, J., Bergelson, J.

2017. Mechanisms to mitigate the trade off between growth and defense. The Plant Cell Online. https://doi.org/10.1105/ tpc.16.00931<Consulted: 01/Sep/2017

Lawrence, C.B., Singh, N.P., Qiu, J., Gardner, R.G., Tuzun, S. 2000. Constitutive hydrolytic enzymes are associated with polygenic resistance of tomato to Alternaria solani and may function as an elicitor release mechanism. Physiological and Molecular Plant Pathology, 57: 211-220.

Luz, J.M.Q., Shinzato, A.V., Silva, M.A.D.

2007. Comparação dos sistemas de produção de tomate convencional e orgânico em cultivo protegido. Bioscience Journal, 23(2): 7-15.

Mazaro, S.M., Wagner, A.J., Santos, I., Citadin, I., Possenti, J.C., Gouvêa, A.

2009. Controle do tombamento de plântulas de beterraba e tomate pelo tratamento de sementes com quitosana. Pesquisa Agropecuária Brasileira, 44: 1424-1430.

Mógor, A.F., Câmara, F.L.A.

2009. Phosphorous and potassium content, and production of organic lettuce over different soil covering. Bioscience Journal, 25(3): 112-118.

Olivares, F.L., Aguiar, N.O., Rosa, R.C.C., Canellas, L.P.

2015. Substrate biofortification in combination with foliar sprays of plant growth promoting bacteria and humic substances boosts production of organic tomatoes. Scientia Horticulturae, 183: 100-108.

Ownley, B.H, Windham, M.T.

2010. Controle Biológico de Fitopatógenos. In: Trigiano, R.N., Windham, M.T., Windham, A.S. (ed.) Fitopatologia conceitos e exercícios de laboratório. Knoxville, Tennessee. p. 447-460.

Pompelli, M.F., França, S.C., Tigre, R.C., Oliveira, M.T., Sacilot, M., Pereira, E.C.

2013. Spectrophotometric determinations of chloroplastidic pigments in acetone, ethanol and dimethylsulphoxide. Revista Brasileira de Biociências, 11: 52-58.

Shaharoona, B., Naveed, M., Arshad, M., Zahir, Z.A.

2008. Fertilizer-dependente efficiency of pseudomonads for improving growth, yeld and nutrient efficiency of wheat (Triticum aestivum L.). Applied Microbiology and Biotechnology, 79: 147-155.

Szilagyi-Zecchin, V.J., Mógor, A.F., Ruaro, L., Röder, C.

2015. Crescimento de mudas de tomateiro (Solanum lycopersicum) estimulado pela bactéria Bacillus amyloliquefaciens subsp. plantarum FZB42 em cultura orgânica. Revista de Ciências Agrárias, 38: 26-33.

Walia, A., Metha, P., Chauhan, A., Shirkot, C.K.

2014. Effect of Bacillus subtilis strain CKT1 as inoculum on growth of tomato seedlings under net house conditions. Biological Sciences, 84(1): 145-155. 
